\title{
The Influence Of Group Leadership And Climate Group To The Empowerment Of Farmer Group In The Village Of Sumber Rejo Beringin Subdistrict Deli Serdang Regency
}

\author{
Yusnadi $^{\mathrm{a}}$, Silvia Mariah $\mathbf{H}^{\mathrm{a}}$

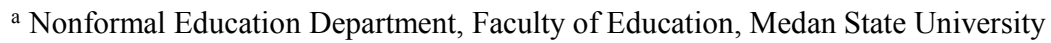 \\ Corresponding e-mail: pede1fip@gmail.com
}

\begin{abstract}
Farmer group is a place for farmers to obtain various innovations in agriculture through the learning process. As a forum for learning, farmer groups should have the independence to develop groups based on their needs, so that groups become empowered. Group empowerment is linked to many factors, including group leadership and group climate. This study aims to analyze the influence of group leadership and group climate on group empowerment. This research was conducted in Sumber Rejo Village of Beringin Subdistrict of Deli Serdang Regency with all members of farmer group as the population, and research sample determined by random or simple random. Data were collected using questionnaire and analyzed using path analysis. The results showed that farmer groups leadership significantly influence farmer groups climate, farmer groups leadership significantly influence groups empowerment, and group climate significantly influence group empowerment at level of trust $\alpha 0,05$.
\end{abstract}

Keywords: Group Leadership, Group Climate, and Group Empowerment

\section{INTRODUCTION}

Farmers have a key position to achieve a tough agriculture. Resilient farmers are farmers who have the ability and opportunity to plan and decide what is best for them, whether individually or collectively or in groups. This kind of condition furthermore is expressed as a an empowerred farmer. To achieve an empowerred farmers an integration from all sectors related to agriculture development are required, one of which is the availability of farmer groups that serve as learning institutions for farmers. Farmers empowering can be related and oriented; (1) the farming economy, (2) the utilization of food security, (3) domestic and foreign markets, (4) science and technology as the spearhead of supplementary increasing value and environmentally friendly technology, and (5) the management industry approach that produces the processed product in a form that is widely available in the market, and not with an industrial approach ${ }^{1)}$.

As the effort to achieve the goal of developing the ability of farmers, the changes in farming is necessary, from traditional to the more advanced modern. Such changes, in educational context are often defined as behavioral changes, which includes knowledge, attitudes, and skills. Such changes can occur in a learning institution for farmers, namely the farmer groups.

The process of farmers behavior changes that lead to the development of farmers who have the ability to apply the innovation, able to deal with various risks, have independent power, require a long time and must go through the learning process.

Farmer group is a place and learning class for farmers. As a place and class of learning, the learning process should refer to the process of farmers empowerment. This is because farmers as learning citizens generally consist of adults who need participative group leadership that can create a conducive group climate ${ }^{2}$.

During this time, agricultural development is only oriented to production, and does not responsive to the market. Farmers are not placed as subjects in planning farming activities developed by farmers, aspirations of farmers are not accommodated maximally. At this point the independence of farmers to determine their own destiny will never be achieved. Various agricultural development programs that were implemented did not directly touch the farmers need, and were very undemocratic, these situations actually made farmers become unempowered ${ }^{3)}$.

In terms of unconducive social-psychological atmosphere that live and grow in the middle of 
farmers, give less fresh air, even tend to opressiveexploitative. Helpless farmers are unable to respond, and they cannot interact with environmental situations actively. As an impact, farmers bhave less and even no power (sense of power), and highly depend on the environment. In these conditions farmers always use the principle of put safety first in every decision-making ${ }^{4)}$. Farmers who highly depend on the environment are helpless farmers, whereas to be a tough, independent, and innovative farmer requires self-empowerment from the farmers themselves.

Farmer groups as learning institution for farmers is a place for farmers to learn and get various innovations in their farm. With the learning process of farmers in farmer groups, farmers should become more empowered, because the learning process is basically a process of empowerment. The empowerment of farmer groups is characterized by an increasing ability of groups, access to adequate information, able to plan their farms, and decide what is best for the group. Group empowerment deals with group leadership that is oriented to the needs of the group, group goals, and focuses on the experiences of group members in leading the group $^{5)}$.

From the above explanation, problems in this research are: (1) does group leadership directly influence on group climate in farmer group? (2) Does group leadership have direct influence on the empowerment of farmer groups? and (3) Does the group climate have a direct effect on the empowerment of farmer groups?

\section{THEORETICAL REVIEW}

\subsection{Group Empowerment}

The word empowerment was originally used in the field of non-formal education, where nonformal education is interpreted as a process of empowerment. As a process of empowerment, nonformal education is concerned with increasing the role of learners to take control in decisionmaking, resources, and institutions that affect their lives. The end product of empowerment is an empowered society. Empowered society is a society that gains understanding and able to control social, economic, and political power in order to improve their position in society. An empowered society are characterized by; (1) Access, having considerable opportunities for obtaining resources; (2) the leverage power, increasing in its collective bargaining power; (3) choices, has the opportunity to determine their choices; (4) status, increased selfimage, self-satisfaction, and has a positive feeling for their identity; (5) the ability of critical reflection, can use experiences to gauge the potential of excellence over the various opportunities of choice in problem solving; (6) the legitimacy, there are expert considerations that refer to or justify rational reasons for the various needs of society; (7) discipline, self-determining quality standards for work performed for others; and (8) creative perception, a more positive and innovative view of relationship with their environment ${ }^{6}$.

\subsection{Climate Groups}

Climate groups are situations that cause each member of the group to feel happy in the group members. The atmosphere of the group is concerned with; (A) the physical condition / place of the group such as the availability of facilities and equipment required by members; And (b) sense of security, which concerns the security of the members to stay in their group, such as no threat, no mutual suspicion, and no mutual hostility ${ }^{7}$. Since group climate is the result of continuing relationships among group members, the climatic climate always refers to the distinctive characteristics of interindividual relationships (interaction) of members within the group. Thus, group climate may be formal / informal or collegial, strict or loose, relaxed or tense, familiar or loose, solidarity or hostile, joyful or sad, etc. ${ }^{8)}$.

Based on the study of climatic theory of the group, it can be concluded that the group climate is the group atmosphere that describes the atmosphere of the group associated with attitudes, emotions and feelings of group members to the group, against the goals of the group and against other members. Indicators of the group climate including; (1) tension, (2) group member hospitality, (3) concessions, and (4) the circumstances of the group.

\subsection{Group Leadership}

Leadership is a process to influence the activities or behaviors of people or group of people, in order to cooperate and work productively to achieve organizational goals ${ }^{9)}$. This opinion is reinforced by Robbns's view, who stated that leadership in the broader sense is to influence a group towards the achievement of group goals ${ }^{10)}$. Achieving group goals by leaders related to how much control and influence a leader has in a group or organization ${ }^{11)}$.

From both views it shows that leadership is related to an optimal efforts of leader to mobilize their subordinates, so subordinates are willing to work together or collaborate and work productively to achieve the established goals. With regard to collaborative leadership, leaders play a role to be able to facilitate all members to interact well to 
achieve common goals. To achieve common goals, collaborative leaders need to pay attention to the quality of self in leadership, among them are; (1) a readiness to take risks, (2) being a sensitive listener, (3) passing positive passions, (3) optimism, and (4) sharing things with knowledge and strength ${ }^{12}$.

Based on theories of leadership that mentioned before, it can be concluded that group leadership is the assessment by members of the group against the way that farmer group leaders do in influencing group members to work together in achieving commonly-defined goals. The indicator of the group leadership are; (1) formulating group goals, (2) decision making (3) exemplary, (4) building cooperation with members, and (5) helping and guiding group members.

\section{RESEARCH HYPOTHESIS}

There are three hypothesis formulated in this research: (1) group leadership influence directly on group climate at farmer group in Sumber Rejo Village of Beringin Subdistrict of Deli Serdang Regency, (2) Leadership group directly influence to farmer group empowerment in Sumber Rejo Village District Beringin Deli Serdang District, and (3) Climate group directly affect the empowerment of farmer groups in Sumber Rejo Village Beringin District Deli Serdang District.

\section{RESEARCH METHODS}

\subsection{Research Design}

The research method used is a survey with a causal approach. Survey results with a causal approach were analyzed quantitatively using path analysis.

\subsection{Population and Sample Research}

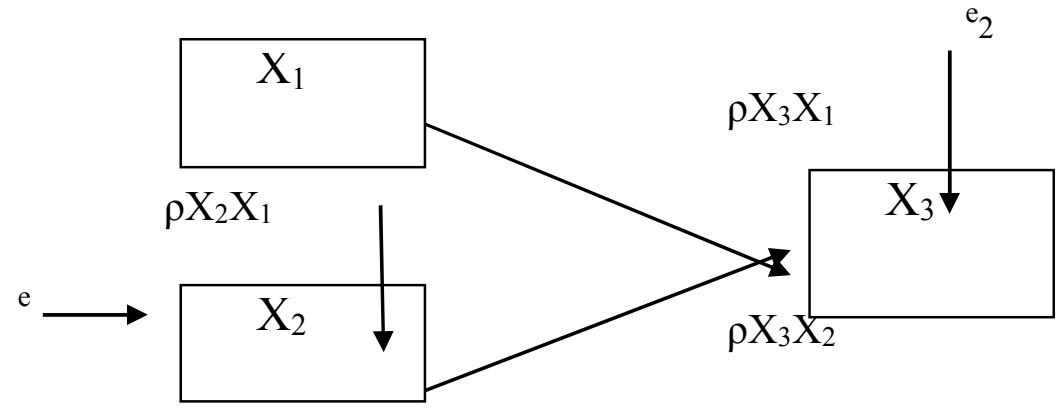

Figure 1. Causal Model Relationship of $X_{1}, X_{2}$, dan $X_{3}$

With reference to the structural equation model, the path diagram is identified into two substructures, namely substructure 1 and substructure 2 . The substructure equation 1 which explains the causal relationship between group leadership $\left(\mathrm{X}_{1}\right)$ and
Research population in this research is all member of farmer group in Sumber Rejo Village, Beringin Subdistrict of Deli Serdang Regency, which are 228 people spread into eight farmer groups. The sample was taken randomly as $5 \%$, so it obtained 135 people. Sampling was taken randomly due to farmers homogeneity.

\subsection{Data Collection}

Data were collected by using Likert scale model questionnaire for all research variables, ie group leadership, group climate, and group empowerment. Each measured variable is considered to be indicators of the research variables. The indicators of each variable serve as a starting point in preparing the items of questions and statements.

For each question or statement, five alternative answers are provided, which are strongly agree, agree, disagree, less disagree, and strongly disagree. There are two types of questions or statements, namely positive and negative. For questions or positive statements strongly agree it will be given a score of 5 , agree a score of 4 , agree less score 3 , disagree score 2, and strongly disagree score 1 . Conversely for negative questions / statements, strongly agree to be 1 , agree to score 2, less Agree to be given a score of 3 , not agreeing to score 4 , and strongly disagree given a score of 5 .

\subsection{Data Analysis}

Data analysis is done through statistics that include; (1) descriptive analysis, (2) requirement test, and (3) hypothesis test. For descriptive analysis is done by calculating the mean, standard deviation, median, mode and determine many classes. To test the requirements of the analysis include test data normality, homogeneity test, linearity test and simple meaning, path analysis, as in Fig. 1 climatic climate $\left(X_{2}\right)$ is: $X_{2}=\rho X_{2} X_{1} X_{1}+{ }^{e} 1$. The second substructure equation describes the causal relationships of group leadership $\left(\mathrm{X}_{1}\right)$ with group empowerment $\left(\mathrm{X}_{3}\right)$ and clauses of group climate 
with group empowerment $\left(\mathrm{X}_{3}\right)$. The equation is: $\mathrm{X}_{3}$ $=\rho X_{3} X_{1} X_{1}+\rho X_{3} X_{2} X_{2}+e_{2}$.

To find the magnitude of the direct effect (DE) of the exogenous variable $\mathrm{X}_{1}$ on the endogenous variable $\mathrm{X}_{3}$ is expressed by the equation: $\mathrm{DEX}_{3} \mathrm{X}_{1}=$ $\left(\rho X_{3} X_{1}\right)\left(\rho X_{3} X_{1}\right)=\left(\left(\rho X_{3} X_{1}\right)^{2}\right.$. Thus DE $X_{1}$ to $X^{3}$ is $\left(\rho X_{3} X_{1}\right)^{2}$ and the magnitude of $D E X_{1}$ to $X^{2}$ is $\left(\rho X_{2} X_{1}\right)^{2}$.

To know the magnitude of indirect effect (IE) from one exogenous variable to endogenous variable is expressed by equation: $\operatorname{IEX}_{3} \mathrm{X}_{1}=\left(\rho \mathrm{X}_{3} \mathrm{X}_{1}\right)$ (rik) $\left(\rho X_{3} X_{2}\right)$. Thus the magnitude of IE variable $X_{1}$ to variable $X_{3}$ through variable $X_{2}$ is $\left(\rho X_{3} X_{1}\right)$ (rik) $\left(\rho X_{3} X_{2}\right)$. Furthermore, the calculation of the total influence (TE) of the exogenous variable on the endogenous variables is used: $\mathrm{TE}=\mathrm{DEi} \mathrm{k}+\mathrm{IEik}=$ $[(\rho \mathrm{ik})+(\mathrm{rkk})((\rho \mathrm{ik})]$.

The hypothesis test is done partially by using Test $\mathrm{t}$, and simultan or together using $\mathrm{F}$ Test on the level siginikansi $\alpha=0.05$.

\section{RESULTS AND DISCUSSION}

\subsection{Descriptive Data Research Results}

Overall the highest score, lowest score, mean score, variance and standard deviation for each research variable are obtained and presented in Table 1.

Table 1. Summarys descriptionof research variables data

\begin{tabular}{|l|c|c|c|c|}
\hline No & Description & $\mathrm{X}_{1}$ & $\mathrm{X}_{2}$ & $\mathrm{X}_{3}$ \\
\hline 1 & Total & 11195 & 10299 & 11640 \\
\hline 2 & Mean & 82,91 & 76,24 & 86,18 \\
\hline 3 & Standart Deviation & 5,605 & 6,591 & 6,673 \\
\hline 4 & Median & 86,6 & 77,11 & 87,35 \\
\hline 5 & Modus & 86 & 82,11 & 89,7 \\
\hline 6 & Highest Score & 94 & 88 & 98 \\
\hline 7 & Lowest Score & 70 & 62 & 71 \\
\hline 8 & Interval & 24 & 26 & 27 \\
\hline 9 & Varians & 31,4124 & 42,401 & 42,3532 \\
\hline
\end{tabular}

1) The Level of Farmers Group Leadership Tendency Variables

The calculation result of ideal ideal value (Mi) and ideal standard deviation ( $\mathrm{SDi}$ ), that is: $\mathrm{Mi}=82$

Table 2. Levell of trends of leadership variable 7leadership of farmer gorup ( $\left.\mathrm{x}_{1}\right)$

\begin{tabular}{|c|c|c|c|c|}
\hline No & Interval & $\mathrm{F}_{\text {Absolute }}$ & F.Relative & Categories \\
\hline 1 & $>87$ & 32 & 23,71 & High \\
\hline 2 & $82-87$ & 52 & 38,52 & Moderate \\
\hline 3 & $76-82$ & 33 & 24,44 & Less \\
\hline 4 & $<72$ & 18 & 13,33 & Low \\
\hline 5 & Total & 135 & 100,00 & \\
\hline
\end{tabular}


3) Level of Cluster Cluster Cluster Variables The calculation result of ideal ideal value (Mi) and ideal Deviation Standard (SDi), that is: $\mathrm{Mi}=84,5$

Table 3. Level of ternds variable climet of farmer groups $\left(\mathrm{x}_{2}\right)$

\begin{tabular}{|c|c|c|c|c|}
\hline No & Interval & $\mathrm{F}_{\text {Absolute }}$ & $\mathrm{F}$.Relative & Categories \\
\hline 1 & $>81$ & 34 & 25,19 & Tinggi \\
\hline 2 & $75-81$ & 49 & 36,30 & Cukup \\
\hline 3 & $\begin{array}{r}69 \\
-75^{69}\end{array}$ & 34 & 25,19 & Kurang \\
\hline 4 & $<69$ & 18 & 13,32 & Rendah \\
\hline 5 & Total & 135 & 100,00 & \\
\hline
\end{tabular}

of Farmer Groups

The ideal ideal (Mi) and ideal Deviation Standard $(\mathrm{SDi})$ calculation results are $\mathrm{Mi}=75$ and $\mathrm{SDi}=4,33$ Next in Table 4, there will be a tendency level of farmer group empowerment variable and SDi $=4,5$. Next in Table 3 will present the level of climate group cluster trend.

Table 4. Level of trends variable of empowerment of farmer groups $\left(\mathrm{x}_{3}\right)$

\begin{tabular}{|c|c|c|c|c|}
\hline No & Interval & $\mathrm{F}_{\text {Absolute }}$ & F.Relative & Categories \\
\hline 1 & $>91$ & 30 & 22,22 & Tinggi \\
\hline 2 & $85-91$ & 56 & 41,48 & Cukup \\
\hline 3 & $78-84$ & 33 & 24,44 & Kurang \\
\hline 4 & $<78$ & 16 & 11,85 & Rendah \\
\hline 5 & Total & 135 & 100,00 & \\
\hline
\end{tabular}

\subsection{Path Model Analysis}

1) Testing Sub Structure 1, namely: Effect of farmer group leadership on farmer group climate. The equation is $X_{2}=\rho 21 X_{1}+\mathrm{e} 1$. A summary of sub-structures 1 is presented in Table 5

Table 5. Testing sub structure 1

\begin{tabular}{|c|c|c|c|c|}
\hline Variable & $\begin{array}{c}\text { Path } \\
\text { Coefficient }(\rho)\end{array}$ & $\begin{array}{c}\text { Determination } \\
\text { Coefficient }(\mathrm{R})\end{array}$ & $\mathrm{T}_{\text {count }}$ & $\mathrm{T}_{\text {tabele }}$ \\
\hline $\mathrm{X}$ & 0,681 & 0,464 & 10,728 & 1,98 \\
\hline
\end{tabular}

2) Testing of Sub Structure 2, that is explaining the influence of farmer group leadership to farmer group empowerment, farmer group climate influence to farmer group empowerment. The equation is $X_{3}=\rho 31 X_{1}+\rho 32 X_{2}+e_{2}$. The summary of sub-structure 2 is presented in Table 6 .

Table 6. Testing sub structure 2

\begin{tabular}{|c|c|c|c|c|}
\hline Variable & $\begin{array}{c}\text { Path } \\
\text { Coefficient }(\rho)\end{array}$ & $\begin{array}{c}\text { Determination } \\
\text { Coefficient }(\mathrm{R})\end{array}$ & $\mathrm{T}_{\text {count }}$ & $\mathrm{T}_{\text {tabele }}$ \\
\hline $\mathrm{X}_{1} \longrightarrow \mathrm{X}_{3}$ & 0,442 & 0,467 & 7,377 & 1,98 \\
\hline $\mathrm{X}_{2} \longrightarrow \mathrm{X}_{3}$ & 0,355 & 0,430 & 6,568 & 1,98 \\
\hline
\end{tabular}

\section{4) Direct and indirect influence}

a. The direct influence of the farmers group's proportional leadership variables toward the farmers group climate is: $\rho 21=0.681$

b. Direct proportional effects of farmer group leadership variables on group empowerment are: $\rho 31=0,442$

c. The direct proportional effect of climatic group variables on the empowerment of farmer groups is: $\rho 32=0.355$ d. The indirect influence of peasant group leadership through farmer group climate on farmer group empowerment is: $\rho 21 . \mathrm{P} 32=0.681 \times 0.355=0.242$.

\subsection{Hypothesis Testing}

1) Hypothesis 1. The leadership of the farmer group has a significant effect on the climate of the farmers group. Based on the calculation results show that $\mathrm{t}$ count $10,728>\mathrm{t}$ table 1.98 . Therefore, the hypothesis is acceptable, that the leadership of the 
farmer group significantly influences the climate of the farmer group.

2) Hypothesis 2. The leadership of the farmer group significantly influences the empowerment of farmer groups. With reference to the results of calculations that show that $\mathrm{t}$ arithmetic $7.377>\mathrm{t}$ table 1.98. Hence, the hypothesis that leadership is stated. Farmer groups have a significant effect on the farmer group's acceptability.

3) Hypothesis 3rd. Climate farmer groups significantly influence farmer group empowerment. Based on the calculation shows that $\mathrm{t}$ count $6.568>\mathrm{t}$ table 1.98. Because $t$ arithmetic greater than $t$ table then the hypothesis that is held, farmer group climate significantly influences the empowerment of farmer groups can be accepted.

To test the hypothesis simultaneously or jointly used the test $\mathrm{F}$. Test $\mathrm{F}$ is intended to determine the quality of regression significance between each of the exogenous variables simultaneously and its effect on endogenous variables. $F$ test results show that $F$ count 26, 437> F table 3, 912 at the trust level of 0.05 . Thus, at the same time, farmer group and peasant group leadership significantly influence farmer group empowerment. Figure 2 shows the calculation of the effect of each research variable.

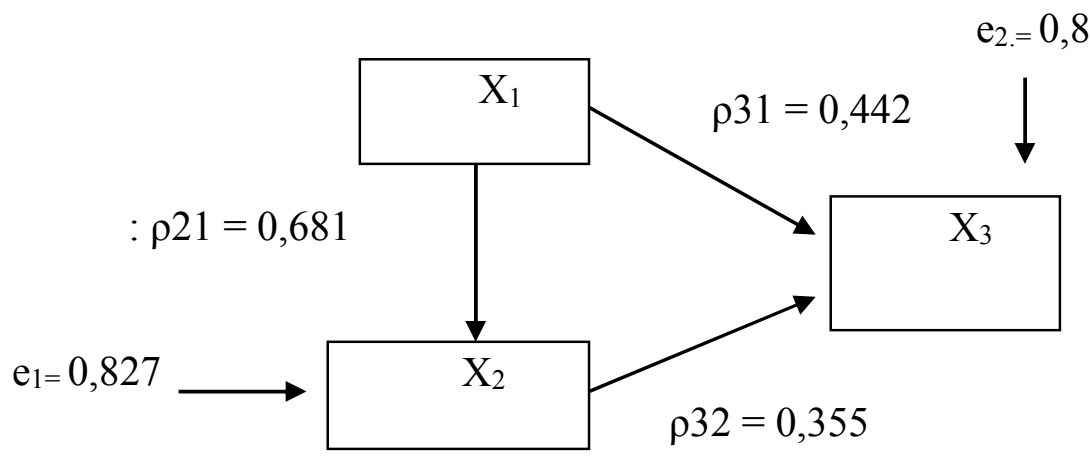

Figure.2 Line Diagram Results of research

Information:

$X_{1}=$ Farmer Group Leadership $\quad \rho 21=$ influence

$\mathrm{X} 1$ to $\mathrm{X}_{2}$

$X_{2}=$ Cluster Farmer Group $\rho 31=$ influence $X 1$ to $\mathrm{X}_{3}$

$X_{3}=$ Empowerment of Farmer Group $\rho 32=$ influence $\mathrm{X} 2$ to $\mathrm{X}_{3}$

$\mathrm{e}_{1} \mathrm{e}_{2}=$ Residual variable

\section{DISCUSSION}

\subsection{Effect of Farmer Group Leadership on Climate Farmer Group}

Based on the path coefficients found significant direct effect of group leadership on the climate of farmer groups. It is found from the amount of the value of $\rho 21=0.681$ and the magnitude of the price of $10.728 \mathrm{t}>\mathrm{t}$ table $=1.98$ at the 0.05 confidence level. Then the magnitude of these effects when viewed at an $\mathrm{R}$ value determination coefficient ( $\mathrm{r} 2$ ) of $0.64 \%$, which means that $64 \%$ of climate influenced by the leadership group of the group, while the rest is determined by other variables outside variables studied.

\subsection{Effect of Farmer Group Leadership on Farmer Group Empowerment}

Based on the path coefficient also found significant direct effect of farmer group leadership on farmer group empowerment. This condition can be seen from the value of $\rho 31=0,442$ and price $t$ arithmetic $=7,377>\mathrm{t}$ table $=1,98$. This proves that the leadership of farmer groups has a significant effect on the empowerment of farmer groups in the village of Sumber Rejo Beringin Deli Serdang District.

\subsection{Climate Group Effect on Farmers Empowerment Group}

From the path coefficient analysis, it was found that the climate of the farmer groups had a direct effect on the empowerment of farmer groups. With reference to the calculation that the amount of $\rho 32=$ 0.355 with the magnitude $\mathrm{t}$ arithmetic $=6.568 \mathrm{Pt}$ table $=1.98$. Thus it can be ascertained that the climate of the farmer group significantly influences the empowerment of farmer groups in the Sumber Rejo village of Beringin Deli Serdang District. Then direct and significant effect was found on the 
coefficient of determination $\mathrm{R}$ (r2) by $53,5 \%$, which means that the empowerment of farmer groups affected by climate leadership farmer groups and farmer groups, while the rest is determined by other variables outside variables studied. Furthermore, it is found that there are the indirect proportional effect of the farmer group's farmer group's variables on the farmers' group's strengths through a farmer group climate of 0.242 .

\section{CONCLUSIONS RECOMMENDATIONS}

AND

\subsection{Conclusion}

With reference to data and data analysis, there are three conclusions that can be generated. Firstly, the leadership of farmer groups significantly influences the climate of farmers' groups. That is, the better the leadership of farmer groups will be the better climate of farmer groups. Variations that occur in farmer group leadership variables amounted to $46,4 \%$, so it can be predicted that in building a good group climate and leadership of farmer groups tend to be in high category.

Secondly, the leadership of farmer groups significantly influences group empowerment. That is, the better the group leadership then the climate of farmer groups will be good. The variation that occurs in peasant group leadership is $46,7 \%$, so it can be predicted in improving the good group climate and the leadership of farmer groups tend to high category.

Thirdly, group climate significantly influences group empowerment. That is, with the better climate of farmer groups, the better the empowerment of farmer groups. The variation in farmer group cluster variables is $43 \%$, so it can be predicted that in increasing group empowerment and climate group farmers tend to be in high category.

\section{Recommendations}

Based on the discussion and conclusion, there are three suggestions that can be made. There are three suggestions that can be given. Firstly, for the leader or head of the farmer's group to further enhance the knowledge, skills and leadership behaviors, thereby increasing his leadership capability in leading the farmer group.

Secondly, members of the farmer group increase their knowledge and skills through various trainings facilitated by farmer groups as a forum for selflearning by farmers.

Thirdly, for further research, it is necessary to conduct further research by involving more predictor and respondent variables, so that other variables suspected to be related to this research can be analyzed so as to obtain more perfect research result.

\section{REFERENCES}

[1] Satari, G., Pembangunan Pertanian dalam Milenium ketiga: Perlu Lembaga Pendidikan Khusus bagi Paradigma Baru Sektor Pertanian. Pikiran Rakyat, hal. 10, tgl. 6 September 1999.

[2] Soetomo, Pembangunan Masyarakat. Yogyakarta, Liberti,1990. hal. 37-39

[3] Kompas, Pertanian: Landasan Dasar Bersama Pembangunan, 11 Oktober 1999.

[4] Scott. J.C., Moral Ekonomi Petani.Terjemahan Hasan Basri. Jakarta, LP3ES,1997, hal.17

[5] Sudjana, D., Strategi Pembelajaran dalam Pendidikan Luar Sekolah. Bandung, Nusanatara Press, 1993 hal. 117

[6] Kindervater, S., Nonformal Education as An Empowering Process. Massachusetts: Center for International Education University of Massachusetts, 1979. p. 13

[7] Hurairah, A., dan Purwanto. Dinamika Kelompok. Bandung, Refika Aditama, 2006. hal. 63.

[8] Yusnadi dan Sani Susanti, Dinamika Kelompok. Medan, Unimed Press, 2014. hal.159

[9] Stoner, James, A.F.,R \& Edward Freeman. Management., USA, Prentice-Hall, Inc. 1992. p.37

[10] Robbins, P. Stephen. Organizational Behaviour: Concept, Controvercies, Aplication. New Jersey, Prentice-Hall International, Inc. 1998. p. 3

[11] Gibson, Ivancevch \& Donnely, Organizations. Terjemahan oleh Djurban Wahid. Jakarta, Erlangga. 1982, hal. 287-292.

[12] Kertamuda, Fachtiah. E., On Becoming A Leader. Yogyakarta. Graha Ilmu. 2015, hal. 63 